\title{
Application of modified red mud in environmentally-benign applications: A review
}

\author{
Collin G. Joseph ${ }^{1,4^{\dagger}}$, Yun Hin Taufiq-Yap ${ }^{2,3}$, Vigneswar Krishnan ${ }^{1}$, Gianluca Li Puma ${ }^{5^{\dagger}}$ \\ ${ }^{1}$ Sonophotochemistry Research Group, Faculty of Science and Natural Resources, Universiti Malaysia Sabah, 88400 Kota Kinabalu, Sabah, Malaysia \\ ${ }^{2}$ Chancellery Office, Universiti Malaysia Sabah, 88400 Kota Kinabalu, Sabah, Malaysia \\ ${ }^{3}$ Catalysis Science and Technology Research Centre, Faculty of Science, Universiti Putra Malaysia, Serdang, Malaysia \\ ${ }^{4}$ Water Research Unit, Faculty of Science and Natural Resources, Universiti Malaysia Sabah, 88400 Kota Kinabalu, Sabah, Malaysia \\ ${ }^{5}$ Environmental Nanocatalysis \& Photoreaction Engineering, Department of Chemical Engineering, Loughborough University, Loughborough, LE11 3TU, UK
}

\section{ABSTRACT}

Red mud (RM) is a waste product that results from bauxite refining via the Bayer process. Its disposal remains an issue which raises significant environmental concerns, particularly if disposed on land or water bodies. Much research has been done on the use of red mud for environmentally-benign applications such as wastewater treatment, catalysis, the production of construction materials and glass ceramics, and for the recovery of metals. This paper reviews the current efforts made in the utilization of red mud as a valuable industrial by-product, which in turn should minimize its harmful impact on the environment. This detailed review compiles and highlights a variety of novel applications of modified red mud as a coagulant, an adsorbent for wastewater treatment, as well as, its use in catalytic processes and in building materials. The physico-chemical properties of red mud can be tuned by a range of treatment methods include acidification, neutralization and heat treatment. As revealed from the literature reviewed, modifications on red mud for the removal of various types of contaminants have shown promising results. However, further amendment and modifications on red mud are needed to utilize this industrial waste in many other industrial applications.

Keywords: Disposal, Red Mud, Utilization, Water treatment

\section{Introduction}

The alumina industry frequently generates a bauxite residue of commercial value namely red mud (RM). On average, between 1 and 1.5 tonne of red mud is generated for every tonne of alumina produced. Since the demand for alumina is increasing worldwide, the generation of red mud is estimated to be 4 billion tonnes by 2015 based on its current production rate [1]. Every tonne of alumina produced roughly generates between 1 and 2 tonne of dry bauxite residues, which varies according to the bauxite source and alumina extraction efficiencies [2]. The nature of red mud depends on the ore source and the technological process parameters used for the production of bauxite. It consists of iron oxides, primarily hematite $\left(\mathrm{Fe}_{2} \mathrm{O}_{3}\right)$, boehmite $(\mathrm{AlOOH})$, and goethite $(\mathrm{FeOOH})$, titanium oxides, calcium oxides, aluminium hydroxides, and sodalite [3]. Chemical analyses has shown that it also contains radionuclides (e.g. ${ }^{40} \mathrm{~K}$, ${ }^{226} \mathrm{Ra}$, and ${ }^{230} \mathrm{Th}$ ), as well as, heavy metals such as Cd, Co, Cr,
$\mathrm{Ni}$ and $\mathrm{V}[4]$.

Due to its alkaline nature ( $\mathrm{pH} 10.0$ to 12.5 ) and the presence of the chemical and mineralogical species, this solid waste causes a significant impact on the environment. Storing red mud in large quantities, however, could prove to be hazardous. Studies have revealed that disposing red mud in the sea has a significant impact on the aquatic ecosystem. The issues regarding the massive generation and subsequent disposal of red mud (Fig. S1) leading to negative impacts continue to be of global concern for the alumina industry, as well as, for the regulatory authorities. Therefore, proper disposal or treatment of waste red mud is necessary in the region where the alumina refinery plants are located. Countless attempts have been made to determine an environmentally safe method to dispose or utilize the red mud waste $[5,6]$.

Various investigators around the world are currently researching new methods for treatment and utilization of red mud. In an attempt to redefine the utilization of red mud, potential applications are
This is an Open Access article distributed under the terms of the Creative Commons Attribution Non-Commercial License (http://creativecommons.org/licenses/by-nc/3.0/) which permits unrestricted non-commercial use, distribution, and reproduction in any medium, provided the original work is properly cited.

Copyright (C) 2020 Korean Society of Environmental Engineers
Received September 6, 2019 Accepted November 18, 2019

${ }^{\dagger}$ Corresponding author

Email: collin@ums.edu.my (Joseph), g.lipuma@lboro.ac.uk (Li Puma) Tel: +6-088-320000 ext. 2117 (Joseph), +44(0)1509222510 (Li Puma) ORCID: 0000-0002-0199-4735 
being investigated and developed. Current strategies include its use as an adsorbent and coagulant material in water and wastewater treatment [7-11], as a catalyst [12, 13], as a building material, for metal recovery, and for ceramic production.

This review focuses on the modifications of the red mud material and its use in wastewater treatment and summarizes the studies made in other areas of interest which utilize red mud as a valuable resource.

\section{Generation of Red Mud}

In 1888, Karl Josef Bayer developed and patented the Bayer process for alumina production. Although alumina can be obtained from bauxite ore by several processes such as the Deville Pechiney process (using sodium carbonate), the Lime Sinter process (using lime), and the Serpeck process (at high temperature with coke and nitrogen), the Bayer process (using sodium hydroxide) is the most economical method, which is in practice for the refinement of bauxite, particularly if this contains a considerable amount of $\mathrm{Fe}_{2} \mathrm{O}_{3}$ [14]. The Bayer process (Fig. S2) involves the digestion of crushed bauxite in concentrated sodium hydroxide (caustic) solution, at elevated temperature and pressure. Under these conditions, the aluminium oxides dissolves, leaving a residue which is known as red mud [15]. The amount of the red mud produced, per tonne of alumina generated, varies greatly depending on the origin of bauxite, from 0.3 tonnes for high grade bauxite to 2.5 tonnes for the very low grade.

Wang and Liu [16] have documented that red mud from the Bayer process consists of dispersive particles compared to sintering red mud. The specific gravity of the Bayer red mud (2.64) determined by pycnometry is higher than that of the sintering red mud (2.47). Fig. S3 shows the typical morphology of red mud [13], which contains a range of particles with different sizes and shapes, mixed with crystals. The major components of Bayer red mud are crystalline boehmite $(\gamma-\mathrm{AlO}(\mathrm{OH}))$, hematite $\left(\mathrm{Fe}_{2} \mathrm{O}_{3}\right)$, gypsum $\left(\mathrm{CaSO}_{4} \cdot 2 \mathrm{H}_{2} \mathrm{O}\right)$, sodalite $\left(\mathrm{Na}_{4} \mathrm{Al}_{3} \mathrm{Si}_{3} \mathrm{O}_{12} \mathrm{Cl}\right)$, and quartz $\left(\mathrm{SiO}_{2}\right)$ with a minor presence of gibbsite $\mathrm{Al}(\mathrm{OH})_{3}$, calcite $\left(\mathrm{CaCO}_{3}\right)$, and whewellite $\left(\mathrm{CaC}_{2} \mathrm{O}_{4} \cdot \mathrm{H}_{2} \mathrm{O}\right)$ [17]. Table 1 shows that the composition of red mud from different locations can vary significantly.

\section{Applications of Red Mud in Wastewater Treatment}

\subsection{Modifications of Red Mud for Adsorption Processes}

The physico-chemical properties of red mud can be tuned by a range of methods including acidification, neutralization and heat treatment (Table 2). Acidification methods improve the removal capacity of red mud of water contaminants by dissolving the calcium and acid-soluble salts, which in turn create new cavities and increase the surface area. Acids used for this purpose include concentrated hydrochloric acids, dilute hydrogen chloride or nitric acids [11, 13, 27-29]. However, contrasting results have also been reported with regards to acid treatment, which was found to dissolve a portion of cancrinite and another type of compounds responsible for adsorption sites [30]. Another study on dye adsorption reports that the acidification treatment which neutralises hydroxide ions on the basic surface favours the removal of basic dyes [18].

Heat treatment on red mud is able to decompose unstable compounds and organics, improving the physico-chemical properties which resulted in higher adsorption capacity. Temperatures ranging from $200^{\circ} \mathrm{C}$ to $1,000^{\circ} \mathrm{C}$ have been investigated in the heat treatment of red mud for the removal of phosphate [28]. In general, heat treatment reduces the specific surface area of red mud (e.g. $700^{\circ} \mathrm{C}$ ) but enhances the adsorption capacity of phosphate removal. During heating phase transition usually occurs (XRD patterns, Fig. S4). For example for the red mud with composition calcite $\left(\mathrm{CaCO}_{3}\right)$, dicalcium silicate $\left(\mathrm{Ca}_{2} \mathrm{SiO}_{4}\right)$, hematite $\left(\mathrm{Fe}_{2} \mathrm{O}_{3}\right)$, gibbsite $\left(\mathrm{Al}(\mathrm{OH})_{3}\right)$, perovskite $\left(\mathrm{CaTiO}_{3}\right)$, and $\mathrm{CaO}$ [28], the gibbsite decomposes into $\mathrm{Al}_{2} \mathrm{O}_{3}$ and $\mathrm{H}_{2} \mathrm{O}$ in the temperature range $300-550^{\circ} \mathrm{C}$, and between $600-800^{\circ} \mathrm{C}$, the calcite phase decomposes into $\mathrm{CaO}$ and $\mathrm{CO}_{2}$. The phases of tricalcium aluminate $\left(\mathrm{Ca}_{3} \mathrm{Al}_{2} \mathrm{O}_{6}\right)$ and Gehlenite $\left(\mathrm{Ca}_{2} \mathrm{Al}_{2} \mathrm{SiO}_{7}\right)$ emerge in the $800-900^{\circ} \mathrm{C}$ interval without obvious mass change or phase change above $900^{\circ} \mathrm{C}$. The acid-heat combined treatment decomposes goethite into a new phase of magnetite. The intensities of hematite also showed a significant enhancement, making them dominant phases in $\mathrm{RM}-\mathrm{HNO}_{3}-700^{\circ} \mathrm{C}$ and RM-HCl- $700^{\circ} \mathrm{C}$ samples. However, Liu [31] observed a loss of acid-soluble fractions such as $\mathrm{Fe}_{2} \mathrm{O}_{3}$ and $\mathrm{CaCO}_{3}$ during the acid

Table 1. Different Compositions of Red Mud from Different Locations

\begin{tabular}{|c|c|c|c|c|c|c|c|c|c|}
\hline \multirow{2}{*}{ Area } & \multicolumn{9}{|c|}{ Composition wt\% } \\
\hline & $\mathrm{Fe}_{2} \mathrm{O}_{3}$ & $\mathrm{Al}_{2} \mathrm{O}_{3}$ & $\mathrm{SiO}_{2}$ & $\mathrm{TiO}_{2}$ & $\mathrm{Na}_{2} \mathrm{O}$ & $\mathrm{CaO}$ & MgO & $\mathrm{K}_{2} \mathrm{O}$ & Ref. \\
\hline HINDALCO, India & 38.80 & 17.28 & 9.64 & 18.80 & 6.86 & - & - & - & [7] \\
\hline Queensland Alumina Ltd. Australia & 34.05 & 25.45 & 17.06 & 4.90 & 2.74 & 3.69 & 1.86 & 0.20 & [8] \\
\hline Slurry pond from Worsley Alumina, Australia & 60.00 & 15.00 & 5.00 & 5.00 & 16.00 & - & - & - & {$[18]$} \\
\hline Aluminium de Gréce S.A. & 45.58 & 15.65 & 6.96 & 7.07 & 3.26 & 14.84 & - & 0.07 & [19] \\
\hline Eurallumina alumina plant, Italy & 30.45 & 17.19 & 9.58 & 8.61 & 12.06 & 7.77 & 0.86 & 0.03 & {$[20]$} \\
\hline Aluminum de Grece & 40.80 & 19.95 & 6.80 & 5.80 & 2.70 & 12.60 & 0.20 & 0.14 & {$[21]$} \\
\hline Shandong Aluminium Corporation, China & 12.76 & 6.93 & 19.14 & 3.43 & 2.37 & 46.02 & 1.15 & 1.20 & {$[22]$} \\
\hline Seydiehir Aluminium Plant, Konya, Turkey & 35.73 & 23.29 & 12.08 & 4.08 & 7.40 & 2.81 & 0.76 & 0.28 & [23] \\
\hline Eurallumina (Porto Vesme, Cagliari, Italy) & 35.20 & 20.00 & 11.60 & 9.20 & 7.50 & 6.70 & 0.40 & - & {$[24]$} \\
\hline Alpart factory and the Alcan Ewarton red mud pond, Jamaica & 45.30 & 18.80 & 4.30 & 6.40 & 1.50 & 3.10 & - & - & {$[25]$} \\
\hline ALCOA factory, San Cibrao (Northwest of Spain) & 37.00 & 12.00 & 9.00 & 20.00 & 5.00 & 6.00 & - & - & [26] \\
\hline
\end{tabular}


Table 2. Modification Methods on Red Mud Tailored to the Adsorption of Selected Water Contaminants

\begin{tabular}{|c|c|c|c|c|}
\hline Treatment & Red mud modification scheme & Target pollutant & Red Mud & Ref \\
\hline Acid heat treatment & $\begin{array}{l}\text { Acid-heat treatment; refluxing red mud in } \mathrm{HCl} \text {; } \\
\text { Addition of } \mathrm{NH}_{3} \text {, calcining at } 500^{\circ} \mathrm{C} \text { for } 2 \mathrm{~h}\end{array}$ & $\mathrm{As}(\mathrm{V})$ & HINDALCO, India & {$[8]$} \\
\hline Acid treatment & $\begin{array}{l}\text { Acid treatment }(0.25-2 \mathrm{M}) \text {; Heat treatment }(200,400 \text {, } \\
\left.600,800^{\circ} \mathrm{C}\right)\end{array}$ & As(III) & $\begin{array}{l}\text { Seyisehir Aluminium Plant } \\
\text { (Konya, Turkey) }\end{array}$ & [34] \\
\hline Acid treatment & $\begin{array}{l}\text { Acid treatment; seawater neutralization; acid and heat } \\
\text { treatment; ferric sulphate or aluminium sulphate } \\
\text { added to neutralize red mud }\end{array}$ & $\operatorname{As}(V)$ & $\begin{array}{l}\text { Queensland Alumina Ltd. } \\
\text { Refinery, Gladstone, Australia }\end{array}$ & {$[35]$} \\
\hline Acid treatment & $\begin{array}{l}\text { Acid treated with } 0.05 \mathrm{M} \mathrm{HCl} \text { at ratio } 1: 25 \text { (wt/wt) } \\
\text { of red mud/ HCl }\end{array}$ & $\begin{array}{l}\mathrm{Pb}(\mathrm{II}) \\
\mathrm{Cd}(\mathrm{II}) \\
\mathrm{Zn}(\mathrm{II})\end{array}$ & $\begin{array}{l}\text { Eurallumina plant (Portovesme, } \\
\text { Sardinia, Italy) }\end{array}$ & {$[30]$} \\
\hline Acid treatment & $\begin{array}{l}\text { Treated with } 2 \mathrm{M} \mathrm{HCl} \text { or } \mathrm{HNO} 3 \text { at liquid/solid ratio } \\
\text { of } 20 \mathrm{ml} \mathrm{g}^{-1} \text {; Calcined the acid pre-treated red mud } \\
\text { at } 700^{\circ} \mathrm{C}\end{array}$ & Phosphate & Worsley Alumina, Australia & {$[28]$} \\
\hline Acid treatment & $\begin{array}{l}\text { Acid treatment with } 0.25 \mathrm{M} \mathrm{HCl} \text {; Heat treatment at } \\
700^{\circ} \mathrm{C}\end{array}$ & Phosphate & $\begin{array}{l}\text { Shandong Aluminum Cop. Ltd., } \\
\text { China }\end{array}$ & {$[36]$} \\
\hline Acid treatment & $\begin{array}{l}\text { Acid-heat treatment at } 80^{\circ} \mathrm{C} \text { with } 0.25 \mathrm{~mol} \mathrm{~L}^{-1} \text {; heat } \\
\text { treated at } 700^{\circ} \mathrm{C}\end{array}$ & Phosphate & $\begin{array}{l}\text { Shandong Aluminum Cop. Ltd., } \\
\text { China }\end{array}$ & [37] \\
\hline Acid treatment & Activated with $10.20 \mathrm{~mol} \mathrm{~L}^{-1}$ of $\mathrm{HCl}$ & Phosphate & $\begin{array}{l}\text { Shandong Aluminum Industry } \\
\text { Corporation (Zibo, China) }\end{array}$ & [11] \\
\hline Acid treatment & $\begin{array}{l}\text { Treated with } 0.5 \mathrm{M} \mathrm{HCl}, 32 \% \mathrm{HCl}, 0.5 \mathrm{M} \mathrm{HNO}_{3}, 70 \% \\
\mathrm{HNO}_{3} \text {, } 0.5 \mathrm{M} \mathrm{H}_{2} \mathrm{SO}_{4} \text { or } 98 \% \mathrm{H}_{2} \mathrm{SO}_{4} \text {, respectively. }\end{array}$ & Fluoride & Australian alumina refinery & [29] \\
\hline Acid treatment & $\begin{array}{l}\text { Soaked in } 1 \mathrm{M} \mathrm{HNO} 3 \text { solution at the } 1: 2 \text { ratio of red } \\
\text { mud and nitric acid }(\mathrm{w} / \mathrm{v}) \text {, activated at } 150^{\circ} \mathrm{C} \text { for } 4 \mathrm{~h} \text {. }\end{array}$ & $\begin{array}{l}\text { Acid Blue } 113 \\
\text { Reactive black } 5\end{array}$ & Bauxite mill, Iran & {$[10]$} \\
\hline Acid treatment & $\begin{array}{l}10 \mathrm{~g} \text { of red mud boiled with } 20 \% \text { wt of } \mathrm{HCl} \text {, dried } \\
\text { at } 40^{\circ} \mathrm{C}\end{array}$ & Congo red & $\begin{array}{l}\text { Etibank Seydisehir Aluminium } \\
\text { Plant (Konya, Turkey) }\end{array}$ & [38] \\
\hline Acid treatment & $\begin{array}{l}\text { Red mud and } 0.5 \mathrm{~mol} \mathrm{~L}^{-1} \mathrm{HCl} \text { at a solid liquid ratio } \\
\text { of } 1 / 20 \text {. }\end{array}$ & $\begin{array}{l}\text { Crystal violet } \\
\text { Malachite green }\end{array}$ & Shandong Aluminum Corporation & [39] \\
\hline Acid treatment & $\begin{array}{l}10 \mathrm{~g} \text { of red mud boiled with } 20 \% \text { wt of } \mathrm{HCl} \text {, dried } \\
\text { at } 40^{\circ} \mathrm{C}\end{array}$ & Phenol & $\begin{array}{l}\text { Seyisehir Aluminium Plant } \\
\text { (Konya, Turkey) }\end{array}$ & {$[40]$} \\
\hline $\begin{array}{l}\text { Addition of metal } \\
\text { halide }\end{array}$ & $\begin{array}{l}10 \mathrm{~g} \text { of red mud in } 1 \mathrm{~L} \text { of water, add } 40 \mathrm{~mL} 0.5 \mathrm{M} \\
\mathrm{FeCl}_{3} \cdot 6 \mathrm{H}_{2} \mathrm{O} \text {, aged for } 1 \mathrm{~d} \text {. }\end{array}$ & $\mathrm{As}(\mathrm{V})$ & $\begin{array}{l}\text { Shandong Aluminium } \\
\text { Corporation, China }\end{array}$ & [41] \\
\hline Composite mixture & $\begin{array}{l}\text { Mixture of red mud ( } 58.7 \mathrm{wt} \%) \text {, kaolin }(25.2 \mathrm{wt} \%) \text {, } \\
\text { sodium silicate solution (11.7 wt\%), fly ash }(2.9 \mathrm{wt} \%) \text {, } \\
\text { and } \mathrm{MgCl}_{2}(1.5 \mathrm{wt} \%) \text {; heat treatment at } 600^{\circ} \mathrm{C}\end{array}$ & $\begin{array}{l}\mathrm{Cu}(\mathrm{II}) \\
\mathrm{Cd}(\mathrm{II}) \\
\mathrm{Pb}(\mathrm{II})\end{array}$ & $\begin{array}{c}\text { Korea General Chemical } \\
\text { Corporation, Daebul Industrial } \\
\text { Park, Korea }\end{array}$ & {$[42]$} \\
\hline Composite mixture & $\begin{array}{l}\text { Mixing dewatered red mud, bentonite and starch at } \\
\text { mass ratios }(95: 5: 5)\end{array}$ & Phosphate & $\begin{array}{l}\text { Shandong Aluminum Cop. Ltd., } \\
\text { China }\end{array}$ & {$[43]$} \\
\hline Composite mixture & $\begin{array}{l}\text { Mixture of red mud ( } 15 \mathrm{~g}) \text {, fly ash }(2 \mathrm{~g}) \text {, sodium } \\
\text { carbonate }(1 \mathrm{~g}) \text {, sodium silicate }(1.2 \mathrm{~g}) \text {, powdered } \\
\text { quicklime }(0.8 \mathrm{~g}) \text {; roast at } 400^{\circ} \mathrm{C} \text { for } 2 \mathrm{~h} \text {, calcined } \\
\text { at } 900^{\circ} \mathrm{C} \text { for } 0.5 \mathrm{~h}\end{array}$ & $\mathrm{Cd}(\mathrm{II})$ & $\begin{array}{l}\text { Shandong Aluminum Cop. Ltd., } \\
\text { China }\end{array}$ & {$[44]$} \\
\hline Composite mixture & $\begin{array}{l}\text { Mixture of neutralized red mud ( } 15 \mathrm{~g}) \text {, dried fly } \\
\text { ash }(2 \mathrm{~g}) \text {, sodium carbonate }(1 \mathrm{~g}) \text {, powdered quicklime } \\
(0.8 \mathrm{~g}) \text { and sodium silicate }(1.2 \mathrm{~g})\end{array}$ & Fluoride & $\begin{array}{c}\text { Etibank Aluminium Plant, Konya, } \\
\text { Turkey }\end{array}$ & {$[45]$} \\
\hline Heat treatment & Treated with $\mathrm{H}_{2} \mathrm{O}_{2}$ and heat treatment at $500^{\circ} \mathrm{C}$ & $\begin{array}{l}\mathrm{Pb}(\mathrm{II}) \\
\mathrm{Cr}(\mathrm{II})\end{array}$ & HINDALCO, India & [7] \\
\hline Heat treatment & Treated with $\mathrm{H}_{2} \mathrm{O}_{2}$ and heat treatment at $500^{\circ} \mathrm{C}$ & $\begin{array}{l}\text { Cd(II) } \\
\text { Zn(II) }\end{array}$ & HINDALCO, India & [46] \\
\hline
\end{tabular}


Table 2. Continued

\begin{tabular}{|c|c|c|c|c|}
\hline Treatment & Red mud modification scheme & Target pollutant & Red Mud & Ref \\
\hline Heat treatment & Treated with $\mathrm{H}_{2} \mathrm{O}_{2}$, activate at $500^{\circ} \mathrm{C}$ & $\begin{array}{c}\text { Fast green } \\
\text { Methylene blue } \\
\text { Rhodamine B }\end{array}$ & $\begin{array}{l}\text { Hindustan Aluminium Company } \\
\text { (HINDALCO), Renukoot, India }\end{array}$ & [47] \\
\hline Heat treatment & $\begin{array}{l}\text { Heat treatment at } 800^{\circ} \mathrm{C} \text { and acid treatment with } 1 \\
\mathrm{M} \mathrm{HNO}_{3}\end{array}$ & & Worsley Alumina, Australia. & [18] \\
\hline Heat treatment & $\begin{array}{l}\text { Seawater to Bayer liquor }(\mathrm{v} / \mathrm{v})(4.5: 1) \text {, Heat treatment } \\
\text { at } 400^{\circ} \mathrm{C}\end{array}$ & Reactive blue 19 & $\begin{array}{l}\text { Alumina plant, Aluminio City, São } \\
\text { Paulo State (Brazil) }\end{array}$ & [48] \\
\hline Neutralization & $\begin{array}{l}\text { Neutralization using sequestration of } \mathrm{CO}_{2} \text { gas; } \\
\text { calcination of neutralized sample at } 500^{\circ} \mathrm{C}\end{array}$ & As(V) & $\begin{array}{l}\text { R \& D Laboratory of NALCO, } \\
\text { Damanjodi, Orissa, India }\end{array}$ & [33] \\
\hline Raw usage & $\begin{array}{l}\text { Filtrate was obtained from red mud slurry (liquid/solid } \\
=2.5 \text { ) }\end{array}$ & As $(V)$ & $\begin{array}{c}\text { Etibank Aluminium Plant, Konya, } \\
\text { Turkey }\end{array}$ & [49] \\
\hline
\end{tabular}

heating process, particularly when the acid concentration or the activation temperature $\left(>700^{\circ} \mathrm{C}\right)$ were too high, or the activation time was too long $(>2 \mathrm{~h})$.

Seawater neutralization treatment is also used to reduce the alkalinity of the red mud without losing the acid neutralization capacity. Thermally activated seawater neutralised red mud was found to remove at least twice the concentration of anionic species than thermally activated red mud alone [32]. Neutralised red mud using $\mathrm{CO}_{2}$ treatment has been successfully applied for the removal of arsenate with promising results. XRD analysis indicated significant differences among $\mathrm{RM}, \mathrm{CO}_{2}$ neutralised $\mathrm{RM}$ and activated $\mathrm{CO}_{2}$ neutralised red mud [33]. An increase in the gibbsite fraction and the formation of a new mineral ilmenite $\left(\mathrm{FeTiO}_{3}\right)$ was revealed as a result of $\mathrm{CO}_{2}$ treatment. Table 2 summarizes physico-chemical treatments of red mud, tailored to the adsorption of target water contaminants.

\subsection{Coagulant Production with Red Mud}

Red mud has been shown to be a promising material for the production of coagulants, due to the presence of a porous structure with a high content of $\mathrm{Fe}$ and $\mathrm{Al}$ [50] and Table 3 reveals a wide range of wastewater contaminants that can be treated using coagulants produced from red mud. Several advantages have been attributed to coagulants produced from red mud in comparison to commercial Fe and $\mathrm{Al}$ salts. These include: (i) one-step coagulation/flocculation process which avoids the use of coagulant aids, or other chemicals; (ii) negligible change of $\mathrm{pH}$ during the purification process; (iii) single step removal of the anionic and cationic species from the wastewater; (iv) one dose usage of coagulant for up to five adsorption contaminants removal cycles; (v) negligible leaching of heavy metals from the waste mud under normal environmental conditions; (vi) safe transport, storage and handling. The activation of red mud for the production of coagulants can be easily obtained using $30 \%$ wt of $\mathrm{H}_{2} \mathrm{SO}_{4}$ with a solid/liquid ratio of 1:5 and contact time $9 \mathrm{~h}$, followed by the neutralisation with waste base [51]. This coagulant has been found effective for the treatment of wastewater generated from pressure washing of boats in marinas.

A highly soluble coagulant (both in solid or concentrated liquid form) with high amounts of $\mathrm{Al}$ and $\mathrm{Fe}$ has been produced by the treatment of red mud in an acidic and saline medium [52]. The optimal conditions for the production coagulant involved the treatment of red mud (20\% w/v) using 1,765 $\mathrm{kg} \mathrm{H}_{2} \mathrm{SO}_{4} /$ ton of treated red mud (trm) and $469 \mathrm{~kg} \mathrm{NaCl} / \mathrm{trm}$ at $110^{\circ} \mathrm{C}$ for $2 \mathrm{~h}$. This coagulant promoted $98 \%$ phosphate removal from a synthetic effluent containing $\mathrm{KH}_{2} \mathrm{PO}$, which was similar to the removal obtained with commercial coagulants containing alum, ferric chloride, and ferric sulphate.

The removal of dyes such as acid red (B), direct blue $\left(\mathrm{B}_{2} \mathrm{R}_{\mathrm{L}}\right)$, and reactive blue (KNR) by coagulation using $\mathrm{MgCl}_{2} / \mathrm{red}$ mud (MRM) has been reported to be superior to the removal with PAC/RM and $\mathrm{PAC} / \mathrm{NaOH}$ coagulants [50]. The effective coagulation effect of MRM on dyes in this case is favoured from the alkalinization of the dyeing solution by the addition of red mud. At $\mathrm{pH}$ higher than 12 , most of the magnesium ions were converted into precipitable magnesium hydroxide, which exhibited adsorptive coagulating behaviour with a large surface area.

The removal phosphate from biologically pre-treated municipal wastewater and eutrophic water by optimized red mud coagulants (hydrochloric pickle liquor of bauxite with w/v 35:100, a calcination temperature at $700^{\circ} \mathrm{C}$, reaction temperature $80^{\circ} \mathrm{C}$ for $4 \mathrm{~h}$ ) has been reported to be 5 to $10 \%$ more efficient than conventional polyaluminum chloride (PACl) (Fig. S5) [53]. Furthermore, leaching test of potential heavy metals from the red mud coagulant confirmed that the coagulant to be non-hazardous.

Efforts have also been made to produce effective polymer-based coagulants from red mud. A novel polyaluminium ferric chloride, PAFC coagulant has been prepared from red mud using $30 \%$ of hydrochloric acid leaching and polymerization processes [54]. $\mathrm{Ca}\left(\mathrm{AlO}_{2}\right)_{2}$ and $\mathrm{NaOH}$ were used as the polymerization adjuster (alkali). In this product, $\mathrm{Ca}\left(\mathrm{AlO}_{2}\right)_{2}$ and $\mathrm{NaOH}$ increased the content of aluminium in the coagulant and improved the coagulant quality. The optimum dosage of PAFC coagulant $\left(0.8 \mathrm{~g} \mathrm{~L}^{-1}\right)$ which was used for the treatment of wastewater from the printing and dyeing industry, achieved residual chemical oxygen demand (COD) lower than $100 \mathrm{mg} \mathrm{L}^{-1}$ and residue turbidity lower than 5 NTU. Red mud has also been used as an alternative alkali to adjust the basicity of the semi-product of polyaluminium chloride (ACl), producing a composite coagulant RMPACl comprised polymeric aluminium species and residual red mud particles with a higher surface area than the raw red mud [55]. Through this process, basicity increased 
Table 3. Production of Various Types of Red Mud-based Coagulants

\begin{tabular}{|c|c|c|c|c|c|}
\hline Target pollutant & Coagulant & Red mud & Coagulant production & Suggested applications of the coagulants & Ref \\
\hline Phosphate & $\begin{array}{l}\text { Composite } \\
\text { coagulant }\end{array}$ & $\begin{array}{l}\text { Shandong Aluminum } \\
\text { Corporation, } \\
\text { Shandong, China. }\end{array}$ & $\begin{array}{l}\text { Calcination temperature of } \mathrm{RM} \\
\left(700^{\circ} \mathrm{C}\right) \text {, w/v ratio of red mud and } \\
200 \mathrm{~mL} \text { hydrochloric pickle liquor } \\
\text { of bauxite }(35: 100) \text {, reaction } \\
\text { temperature }\left(80^{\circ} \mathrm{C}\right), \mathrm{pH}(6.2)\end{array}$ & $\begin{array}{l}\text { This coagulant could be effectively } \\
\text { used in tertiary treatment of } \\
\text { biologically pre-treated municipal } \\
\text { sewage while in eutrophic wastewater. } \\
\text { Its performance was better compared } \\
\text { to PACl }\end{array}$ & [53] \\
\hline Phosphate & RMPACl & $\begin{array}{l}\text { Shandong Aluminum } \\
\text { Corporation, } \\
\text { Shandong, China. }\end{array}$ & $\begin{array}{l}\mathrm{w} / \mathrm{v} \text { ratio of red mud to } \mathrm{ACl}(0.25) \text {, } \\
\text { water bath temperature }\left(80^{\circ} \mathrm{C}\right), 2 \mathrm{~h}\end{array}$ & $\begin{array}{l}\text { Phosphate removal from the Xiang Xi } \\
\text { river water in the Hubei province was } \\
\text { performed. } \\
\text { RMPACl performed better than PACl } \\
\text { at a low dosage in the phosphate } \\
\text { removal from real water. }\end{array}$ & [55] \\
\hline Phosphorus & $\begin{array}{c}\mathrm{J} 1 \\
\text { coagulant }\end{array}$ & $\begin{array}{l}\text { Vaudreuil } \\
\text { Aluminium Factory } \\
\text { in Jonquière } \\
\text { (QC, Canada) }\end{array}$ & $\begin{array}{l}\mathrm{H}_{2} \mathrm{SO}_{4} \text { concentration }(6.0 \mathrm{~N}), \mathrm{NaCl} \\
\left(93.8 \mathrm{~g} \mathrm{~L}^{-1}\right) \text {, leaching period }(120 \mathrm{~min}) \text {, } \\
\text { solids concentration }\left(200 \mathrm{~g} \mathrm{~L}^{-1}\right) \text {, } \\
\text { temperature }\left(110^{\circ} \mathrm{C}\right) .\end{array}$ & $\begin{array}{l}\text { The performance of this coagulant } \\
\text { was similar to the commercially } \\
\text { available coagulant }\end{array}$ & [52] \\
\hline $\begin{array}{l}\text { Pretreated oily sewage, } \\
\text { printing and dyeing } \\
\text { wastewater }\end{array}$ & PAFC & $\begin{array}{l}\text { Shandong Weiqiao } \\
\text { aluminium \& } \\
\text { electricity Co.Ltd., } \\
\text { Shandong, China }\end{array}$ & $\begin{array}{l}30 \% \text { of } \mathrm{HCl}(300 \mathrm{~mL}) \text { and } \mathrm{RM}(100 \mathrm{~g}) \text {, } \\
\text { mother liquor and washing liquor } \\
(100 \mathrm{~mL}) \text { were mixed with } \mathrm{Ca}\left(\mathrm{AlO}_{2}\right)_{2} \\
(1.5 \mathrm{~g}) \text { and } \mathrm{NaOH}(1.2 \mathrm{~g}), 80^{\circ} \mathrm{C}\end{array}$ & $\begin{array}{l}\text { Application in the pretreated oily } \\
\text { sewage and in printing and dyeing } \\
\text { wastewater treatments. }\end{array}$ & [54] \\
\hline $\begin{array}{l}\text { Direct blue, reactive } \\
\text { blue, acid red dyes }\end{array}$ & MRM & $\begin{array}{l}\text { Shandong Aluminum } \\
\text { Corporation, } \\
\text { Shandong, China. }\end{array}$ & $\begin{array}{l}\text { Mg powder and } 20 \% \mathrm{HCl} \text { (Solid: } \\
\text { liquid ratio }(\mathrm{g} / \mathrm{L})=175: 1) \text {; mixture of } \\
\mathrm{MgCl}_{2} \text { and } \mathrm{RM}\end{array}$ & $\begin{array}{l}\text { MRM coagulant could be effectively } \\
\text { used as an alternative to some of the } \\
\text { conventional treatments, particularly, } \\
\text { in the textile wastewater industry. }\end{array}$ & {$[50]$} \\
\hline
\end{tabular}

from $2.1 \%$ to $77.3 \%$ as the $\mathrm{RM} / \mathrm{ACl}$ ratio increased from 0 to 0.5 . As a result, RMPACl $\left(147.5 \mathrm{mgL}^{-1}\right)$ showed better coagulation performance (94.9\%) than PACl (175 $\mathrm{mg} \mathrm{L}^{-1}$ ) which yielded only $92.3 \%$ in the treatment of synthetic and natural phosphate contaminated wastewater.

\subsection{Adsorbent Development}

\subsubsection{Removal of heavy metals and metal ions with red mud}

Red mud has been used as a viable adsorbent for heavy metals adsorption such as $\mathrm{As}(\mathrm{III}), \mathrm{As}(\mathrm{V}), \mathrm{Cd}(\mathrm{II}), \mathrm{Cr}(\mathrm{V}), \mathrm{Cu}(\mathrm{II}), \mathrm{Ni}(\mathrm{II}), \mathrm{Pb}(\mathrm{II}), \mathrm{Zn}(\mathrm{II})$ in wastewater. Toxicity characteristic leaching procedure (TCLP) tests before and after metals removal have shown that red mud is an environmentally compatible material that could be used for wastewater treatment [56]. Modifications of raw red mud with heat treatment, acid treatment, and other developing methods have been reported to improve the removal of heavy metals from aqueous system.

Arsenic is a toxic element at higher concentration, commonly found in the groundwater of certain countries such as Bangladesh, Brazil, Canada, China, India, and Nepal. Mining, smelting of arsenic-bearing minerals are the main causes of the high abundance of arsenic species $(-\mathrm{III}, 0,+\mathrm{III}$ and $+\mathrm{V})$ in groundwater. Inorganic As(III) and As(IV) are known to be more toxic compared to its methylated forms monomethyl arsenic acid (MMA) and dimethyl arsenic acid (DMA) [57-59], while arsenate (As(V)) is highly toxic. The adsorption of arsenic from water with acid and heat treated red mud is $\mathrm{pH}$ dependent. The optimum $\mathrm{pH}$ range has been reported to be 5.8 - 7.5 for As(III) adsorption (exothermic process) and 1.8-3.5 for $\mathrm{As}(\mathrm{V})$ (endothermic process) [34, 60]. A process for the removal of $\mathrm{As}(\mathrm{V})$ using liquid phase red mud (LPRM, 2.5 liquid/slurry ratio) and coagulation has been proposed [49]. The As(V) removal comprises the two steps of neutralization of LPRM-arsenical solution mixtures in acidic condition followed by air-agitation and $\mathrm{CO}_{2}$-neutralization. As(v) can be removed effectively from the mixture of LPRM-As(v) solution using an optimal Al/As (V) molar ratio of 6-8. Arsenate can also be effectively removed using seawater-neutralized red mud (bauxsol) [8] in adsorption columns packed with bauxsol coated sand (BCS) (1.64 $\left.\mathrm{mg} \mathrm{g}^{-1}\right)$ and activated bauxsol coated sand (ABCS) (3.14 $\mathrm{mg} \mathrm{g}^{-1}$ ) (Fig. S6). Most of the sorbed $\mathrm{As}(\mathrm{V})\left(0.39-8.76 \mathrm{mmol} \mathrm{\textrm {kg } ^ { - 1 }}\right)$ is usually associated with amorphous and crystalline $\mathrm{Al}$ and Fe oxides (24.1 - 43.8\% and 24.7 $59.0 \%$ of total sorbed arsenic) [61] with the percentage distribution related to the surface coverage of arsenic.

The adsorption of arsenate is usually significantly affected by the $\mathrm{pH}$ of the water and the adsorption capacity increases as $\mathrm{pH}$ decreases, however, the highest absorption capacity of $\mathrm{FeCl}_{3}$ modified red mud (68.5 $\left.\mathrm{mg} \mathrm{g}^{-1}\right)$ is obtained at $\mathrm{pH} 6$ [41]. Among the ions present in the water, nitrate ion has little impact, $\mathrm{Ca}^{2+}$ enhances the adsorption process, whereas $\mathrm{HCO}_{3}{ }^{-}$decreases the adsorption of arsenate. The spent $\mathrm{FeCl}_{3}$ modified red mud can be regenerated up to $92 \%$ by using $0.2 \mathrm{~mol} \mathrm{~L}^{-1} \mathrm{NaOH}$. Using activated $\mathrm{CO}_{2}$-neutralized red mud (ANRM) [33] the most effective removal of arsenate is obtained at $\mathrm{pH}$ 4. The high adsorption of arsenate on ARNM is attributed to the hydroxyl surfaces mixture of Fe, $\mathrm{Al}$, and $\mathrm{Ti}$ oxides, which provides strong adsorption affinity by forming inner-sphere complexes. Again, the arsenate-adsorbed ANRM can be easily regenerated using $\mathrm{NaOH}$ solution at $\mathrm{pH}$ 12.0.

Effective removal of other heavy metals $\left(\mathrm{Cr}^{2+}, \mathrm{Pb}^{2+}, \mathrm{Cd}^{2+}\right.$ and 
$\mathrm{Zn}^{2+}$ ) in both batch and column configurations can be achieved using activated red mud (ARM) [7, 46]. High capacity ARM is made by treating red mud with $\mathrm{H}_{2} \mathrm{O}_{2}$ and calcination at $500^{\circ} \mathrm{C}$. The adsorption capacity for chromium has been reported to be 1.3 times higher than that for lead, while the presence of other metal ions $\left(\mathrm{Na}^{+}, \mathrm{Cd}^{2+}, \mathrm{Zn}^{2+}\right.$ ) and surfactants (manaxol 1B, cetyltrimethyl ammonium bromide) reduces the removal of $\mathrm{Cr}^{2+}$ and $\mathrm{Pb}^{2+}$ [7]. At low ions concentrations, remarkable removal of efficiency of $\mathrm{Cd}^{2+}(0.02 \mathrm{mM})$ and $\mathrm{Zn}^{2+}(0.03 \mathrm{mM})$ has been reported at $\mathrm{pH} 4$ using $10 \mathrm{~g} \mathrm{~L}^{-1}$ of ARM [46].

A new pellet type adsorbent produced with red mud, kaolin, sodium silicate solution, fly ash, and $\mathrm{MgCl}_{2}$ at $600^{\circ} \mathrm{C}$ has been shown to be highly effective for the removal (> 95\%) of $\mathrm{Cu}^{2+}$, $\mathrm{Cd}^{2+}$ and $\mathrm{Pb}^{2+}$ from aqueous systems [42]. Continuous adsorption experiments confirmed that this adsorbent is more effective in the removal of $\mathrm{Pb}^{2+}$ among the heavy metals tested. Granular red mud (GRM) has also been examined for the removal of cadmium from aqueous solutions [44]. The adsorption process in the GRM-Cd ${ }^{2+}$ system at initial $\mathrm{pH} 6.0$ was found to be controlled primarily by intraparticle-diffusion. The maximum adsorption capacities of GRM were determined to be $38.2 \mathrm{mg} \mathrm{g}^{-1}$ at $20^{\circ} \mathrm{C}, 43.4 \mathrm{mg} \mathrm{g}^{-1}$ at $30^{\circ} \mathrm{C}$ and $52.1 \mathrm{mg} \mathrm{g}^{-1}$ at $40^{\circ} \mathrm{C}$.

Acid treated $(\mathrm{HCl})$ red mud containing a high amount of cancrinite, however, has been reported deleterious for the adsorption of heavy metals $\left(\mathrm{Cd}^{2+}, \mathrm{Pb}^{2+}\right.$, and $\left.\mathrm{Zn}^{2+}\right)$ in comparison to untreated red mud [30]. The adsorption capacity of the untreated red mud for $\mathrm{Cd}^{2+}, \mathrm{Pb}^{2+}$, and $\mathrm{Zn}^{2+}$ was $1.35 \mathrm{mmol} \mathrm{g}{ }^{-1}, 1.88 \mathrm{mmol} \mathrm{g}^{-1}$, and $2.47 \mathrm{mmol} \mathrm{g}^{-1}$, respectively, while, it decreased by $30 \%$ using $\mathrm{HCl}$ treated red mud. Acid treatment in this case decreases the amount (by $8.2 \%$ ) and pore structure of cancrinite and other phases of the red mud, which are responsible for adsorption sites. In contrast, the presence of a higher amount of cancrinite in the untreated red mud facilitates the incorporation of $\mathrm{Pb}, \mathrm{Cd}$, and $\mathrm{Zn}$ in the cages and channels of its lattice.

Boron as borate is a problematic ion to be removed from aqueous systems. Neutralized red mud is highly effective for the removal of boron from aqueous systems [62]. The adsorption of boron as borate anions is negligibly affected in the $\mathrm{pH}$ range from 2 to 7 and equilibrium is readily achieved within 20 min of contact time. The results are more accurately modelled by the Freundlich isotherm rather than by the Langmuir isotherm, which indicated a heterogeneous adsorption process. Table 4 compares the Freundlich isotherm constants $(k, n)$ for the adsorption of boron using a range of adsorbents and it shows a several order increase in the adsorption capacity of neutralized red mud.

Table 4. The Freundlich Isotherm Constants $(k, n)$ for Adsorption of Boron by Different Adsorbents [62]

\begin{tabular}{lccc}
\hline Adsorbents & $\boldsymbol{k}\left(\mathbf{m g ~ g}^{-\mathbf{1}}\right)$ & $\mathbf{n}$ & Ref \\
\hline Activated carbon & 0.19 & 2.5 & {$[63]$} \\
Activated alumina & 0.44 & 1.4 & {$[63]$} \\
Minespoils (Wooley Edge) & 0.004 & 1.4 & {$[64]$} \\
Minespoils (Hoyland Common) & 0.005 & 1.6 & {$[64]$} \\
Minespoils (Crowedge) & 0.002 & 1.9 & {$[64]$} \\
Neutralized red mud & 5.996 & 2.2 & {$[62]$} \\
\hline
\end{tabular}

\subsubsection{Removal of inorganic ions with red mud}

Phosphate: The removal of phosphate has been reported using heat activated and acid activated red mud [37]. The optimum activation of red mud is obtained after calcination at $700^{\circ} \mathrm{C}$ for $2 \mathrm{~h}$, while in the acid-heat activated process (RMAH), the highest performance is obtained after treatment at $80^{\circ} \mathrm{C}$ with $0.25 \mathrm{~mol}$ $\mathrm{L}^{-1} \mathrm{HCl}$ for $2 \mathrm{~h}$. At $\mathrm{pH}$ 7, the RMAH and RM700 achieved 31.0 and $30.7 \mathrm{mg} \mathrm{g}^{-1}$ removal from a solution with an initial phosphate concentration of $155 \mathrm{mg} \mathrm{L}^{-1}$. The Langmuir isotherm model indicated that the maximum sorption capacities of phosphate by the RMAH and RM700 were $203 \mathrm{mg} \mathrm{g}^{-1}$ and $155 \mathrm{mg} \mathrm{g}^{-1}$. The loss of acid-soluble fractions such as $\mathrm{Fe}_{2} \mathrm{O}_{3}$ and $\mathrm{CaO}$ in the residue was observed during the acid-heat process when either the $\mathrm{HCl}$ concentration or the activation temperature was too high. In a comparative study between raw RM and ARM [28], the greatest adsorption capacity of ARM was $0.58 \mathrm{mg} \mathrm{g}^{-1}$ at $\mathrm{pH} 5.5\left(40^{\circ} \mathrm{C}\right)$ while raw RM only yielded $0.23 \mathrm{mg} \mathrm{g}^{-1}$ under similar experimental conditions. The adsorption of phosphate was improved by $25 \%$ when the temperature increased from 30 to $40^{\circ} \mathrm{C}$. The authors demonstrated that the adsorption of phosphate was a heterogeneous adsorption with two major phosphate species, $\mathrm{H}_{2} \mathrm{PO}_{4}{ }^{-}$and $\mathrm{HPO}_{4}{ }^{2-}$.

Red mud granular adsorbents (RMGA) prepared using different mass proportion of raw materials (red mud, bentonite and starch) at different sintering temperatures (ST) have been assessed for the adsorption of phosphate at selected aquatic temperatures (AT) $\left(17^{\circ} \mathrm{C}, 27^{\circ} \mathrm{C}, 37^{\circ} \mathrm{C}\right)[65]$. The RM ratio in the RMGA and ST influenced the characteristics of the RMGA more significantly than other factors. The optimum parameters, under which the largest adsorption capacities could be achieved, varied with different AT. The optimum ST was $1,080^{\circ} \mathrm{C}, 1,050^{\circ} \mathrm{C}$ and $1,030^{\circ} \mathrm{C}$ for RMGA- $85 \%$ under AT of $17^{\circ} \mathrm{C}, 27^{\circ} \mathrm{C}$, and $37^{\circ} \mathrm{C}$, respectively, and for RMGA- $90 \%$, it was $1,050^{\circ} \mathrm{C}, 1,010^{\circ} \mathrm{C}$, and $980^{\circ} \mathrm{C}$, respectively, at different $\mathrm{AT}$. In the following study, the regeneration of RMGA (RM, bentonite, and starch at a ratio of 95:5:5) used for phosphate removal using various desorption reagents was investigated [43]. The generation of the sorbent was found optimal using a $0.01 \mathrm{~mol} \mathrm{~L}^{-1} \mathrm{NaOH}$ solution, considering both an optimum regeneration capacity and the process economics. Another study, reported the mechanism of adsorption of phosphate from aqueous solution using RMGA, which involved two stages of adsorption and precipitation [66].

Recently, the interaction between acid activated-neutralized red mud (AaN-RM) and phosphate was examined [11]. The phosphate adsorption capacity of AaN-RM was found to be $492 \mathrm{mg} \mathrm{g}^{-1}$. The phosphate adsorption was described as the chemisorption of phosphate on AaN-RM and the process was described as heterogeneous. The formation of phosphate complexes (Al-P, Al-P- $\mathrm{H}_{3} \mathrm{PO}_{4}, \mathrm{Fe}-\mathrm{P}$, and $\mathrm{Fe}-\mathrm{P}-\mathrm{H}_{3} \mathrm{PO}_{4}$ ) on the AaN-RM surface can be attributed to surface deposition, ion exchange, and precipitation mechanisms. $60 \%$ of the sorbed phosphate onto AaN-RM was through ion exchange and precipitation with strong chemical bonds, while the remaining phosphate was adsorbed via surface deposition with weak chemical bonds.

Fluorides and Nitrates: Batch and column studies have been conducted using granular red mud (GRM) on fluoride removal [45]. The maximum adsorption of fluoride in batch experiments was $0.644 \mathrm{mg} \mathrm{g}^{-1}$ (pH 4.7) and equilibrium was reached after $6 \mathrm{~h}$. The results indicated that the sorption capacities determined from columns studies were higher (0.773-1.274 $\mathrm{mg} \mathrm{g}^{-1}$ for $5 \mathrm{~g} \mathrm{~L}^{-1} \mathrm{GRM}$ 
dosage) than in batch tests. The discrepancy was explained by the presence of GRM pores that favour improved solid state diffusion in the column tests relative to the batch tests. However, concentrated acids were found to have a negative effect on fluoride adsorption due to the loss of active sites [29]. The ionic charge of aluminium and iron oxide/hydroxides on the surface of the red mud strongly influenced the adsorption of fluoride. The acidification of red mud with strong acids transforms the $\equiv \mathrm{SOH} \equiv \mathrm{SO}^{-}$sites to $\equiv \mathrm{SOH}_{2}+$ which replaces a proton $\left(\mathrm{H}^{+}\right)$with fluoride.

The removal of nitrate using $\mathrm{HCl}$ activated red mud has been reported in batch adsorption experiments [67]. The nitrate adsorption capacity of activated red mud (5.86 mmol g-1) was found to be higher than that of the non-activated red mud $\left(1.86 \mathrm{mmol} \mathrm{g}^{-1}\right)$ and decreased above $\mathrm{pH}$ 7. The nitrate saturation capacity of activated red mud was three times higher when compared to non-activated red mud.

\subsubsection{Dye adsorption on red mud}

Growing concern has been reported with regards to the potential adverse effects of textile dyes on aquatic ecosystems and humans due to the exposure of contaminated drinking and recreational waters [68]. The use of modified red mud for dyes adsorption has yielded promising results and has been reported in numerous studies. The chemistry of the dye molecules and of activated red mud in aqueous solution is strongly influenced by the $\mathrm{pH}$. The removal of fast green, methylene blue, and rhodamine $\mathrm{B}$ has been reported 94.0, 75.0 and 92.5\% respectively, using 10.0 $\mathrm{g} \mathrm{L}^{-1}$ of modified red mud [47], and the optimum $\mathrm{pH}$ for the removal were 8.0, 7.0, and 1.0, respectively. The adsorption of dyes decreased as the temperature increased from $30^{\circ} \mathrm{C}$ to $50^{\circ} \mathrm{C}$. The presence of anionic and cationic surfactants [manoxol $1 \mathrm{~B}$ and cetyltrim-ethylammonium bromide (CTAB), respectively] in dye solutions resulted in a decrease in the adsorption of the dyes.

The effect of $\mathrm{pH}$ and the temperature was also studied for the adsorption of methylene blue from aqueous solutions using fly ash and red mud [18]. Raw fly ash showed greater adsorption than red mud with adsorption capacity of 14.0 and $7.8 \mu \mathrm{mol} \mathrm{g}^{-1}$, respectively. Acid treatment and heat treatment of red mud at $800^{\circ} \mathrm{C}$ exhibited lower adsorption capacity compared to virgin red mud. The treatment at high temperature on red mud decomposes organic compounds and hydroxyl groups, which may create effective sites for adsorption. Acid treatment also reduced the basicity of red mud, which favours the adsorption of basic dyes. The adsorption of methylene blue on red mud was an endothermic reaction with $\Delta \mathrm{H}^{\mathrm{o}}$ of $10.8 \mathrm{~kJ} \mathrm{~mol}^{-1}$.

The adsorption of cationic dyes on red mud is favoured under basic conditions. The removal of crystal violet (CV) and malachite green (MG) with acid-activated sintering red mud (ASRM) [39] is a rapid process and was completed in $90 \mathrm{~min}$ and $180 \mathrm{~min}$ for CV and MG respectively. The Langmuir isotherm model described the adsorption of these dyes more accurately than the Freundlich isotherm model, with adsorption capacities of $60.5 \mathrm{mg}$ $\mathrm{g}^{-1}$ and $336.4 \mathrm{mg} \mathrm{g}^{-1}$ for CV and MG, respectively. The adsorption of these dyes was favoured at $\mathrm{pH}$ higher than the $\mathrm{pH}_{\mathrm{pzc}}$ of ASRM (3.2) as a result of the electrostatic interaction between the positively charged $\left(-\mathrm{N}^{+}\right)$groups of the cationic dyes and the negatively charged surface of ASRM presented by ion exchange Reaction (1) or Si-O-Si structures Reaction (2).

ASRM-OH $+\mathrm{N}^{+}\left(\left(\mathrm{CH}_{3}\right)_{2}\right)$-dye $\rightarrow$ ASRM-O-N $\left(\left(\mathrm{CH}_{3}\right)_{2}\right)$-dye $+\mathrm{H}^{+}(1$
ASRM-Si-O $+\mathrm{N}^{+}\left(\left(\mathrm{CH}_{3}\right)_{2}\right)$-dye $\rightarrow$ ASRM-Si-O-N $\left(\left(\mathrm{CH}_{3}\right)_{2}\right)$-dye

In contrast to cationic dyes, the adsorption of anionic dyes is favoured at $\mathrm{pH}$ lower than the $\mathrm{pH}_{\mathrm{pzc}}$ of the sorbent. The adsorption of reactive black 19 (RB19) onto seawater-neutralised red mud (SWNRM) which have $\mathrm{pH}_{\mathrm{pzc}}(9.0 \pm 0.2)$ was investigated [48]. Red mud samples were treated with seawater as shown in Table 2. The highest removal of RB19 was obtained for the SWNRM sample heated to $400^{\circ} \mathrm{C}$, and at $\mathrm{pH}$ less than the $\mathrm{pH}_{\mathrm{pzc}}$. From the adsorption data, the maximum adsorption capacities were 250.0 $\mathrm{mg} \mathrm{g}^{-1}$, $416.7 \mathrm{mg} \mathrm{g}^{-1}$ and $384.6 \mathrm{mg} \mathrm{g}^{-1}$ for SWNRM, SWNRM400 and SWNRM500, respectively.

The adsorption capacities of modified red mud for various types of dyes are summarized in Table 5. The removal of a diazo dye, congo red from aqueous solution with activated red mud [38] was optimum at $\mathrm{pH} 7.0$ and equilibrium was reached in $90 \mathrm{~min}$. The maximum adsorption capacity of congo red on ARM was 7.08 mg $\mathrm{g}^{-1}$.

In further studies, the removal of anionic dyes, acid blue 113 (AB113) and reactive black 5 (RB5) using acid activated red (ARM) mud after $60 \mathrm{~min}$ were $3871 \mathrm{mg} \mathrm{kg}^{-1}$ and $2406 \mathrm{mg} \mathrm{kg}^{-1}$, respectively [10]. The removal of AB113 and RB5 decreased from 97\% to $88 \%$ and $58 \%$ to $11 \%$, respectively, when the $\mathrm{pH}$ of the solution $\mathrm{pH}$ increased from 3 to 11 . This phenomenon can be described by the amphoteric behaviour of adsorbent which has $\mathrm{pH}_{\mathrm{pzc}}$ (8.96). The presence of aniline and phenol groups on RB5 lessens its interaction with the positively charged surface of ARM especially below $\mathrm{pH}$ 8.96. The removal of AB113 was higher than RB5 because of the greater molecular size of RB5 which prevents it from approaching to the adsorbent surface. The maximum adsorption capacities were $83.3 \mathrm{mg} \mathrm{g}^{-1}$ and $35.6 \mathrm{mg} \mathrm{g}^{-1}$ at $\mathrm{pH} 3$ for $\mathrm{AB} 113$ and RB5, respectively.

\subsubsection{Adsorption of phenolic compounds on red mud}

Effluents containing phenol and derivative compounds generated from industrial operations such as pharmaceutical production, polymer production, and petrochemicals operations are often toxic and carcinogenic due to the stability of phenolics species in aqueous systems. The removal of phenol using $\mathrm{HCl}$ activated red mud was found to have negligible effect in comparison to unmodified red mud [72]. The authors explained that changes in the electrostatic, hydrophilic and hydrophobic characteristics of red mud imparted by $\mathrm{HCl}$ treatment, resulted in weak interactions between the sorbed phenol molecules and the surface of the red mud and this facilitated the desorption of the bonded phenols. A contrasting study reported the removal of phenol by 33\% with neutralized red mud and 70\% with acid activated neutralized red mud [45]. Another study using neutralized red mud reported that the removal of phenol was obtained in a wide $\mathrm{pH}$ range from 1 to 9 though a spontaneous process. The maximum monolayer sorption capacity for the adsorption of phenol was found to be $4.12 \mathrm{mg} \mathrm{g}^{-1}$. The higher selectivity of metal oxides present in the red mud showed that an increasing chloride dosage had no effect on the phenol adsorption, as compared to sulphate and nitrate ions [40].

The adsorption of phenol, 2-chlorophenol, 4-chlorophenol and 
Table 5. Adsorption Capacity of Modified Red Mud for Different Class of Dyes

\begin{tabular}{|c|c|c|c|c|c|}
\hline Classification of dye & Dye & Adsorbent & pH & Adsorption (mg g ${ }^{-1}$ ) & Ref. \\
\hline \multirow{6}{*}{ Anionic } & Acid blue 113 & $\mathrm{RM}-\mathrm{HNO}_{3}$ & 3 & 35.58 & [10] \\
\hline & Congo red & RM-HCl & 7 & 7.08 & [38] \\
\hline & Remazol brilliant blue & $\mathrm{RM}-\mathrm{H}_{2} \mathrm{SO}_{4}$ & $2-6$ & 27.80 & [69] \\
\hline & Reactive black 5 & $\mathrm{RM}-\mathrm{HNO}_{3}$ & 3 & 83.33 & [10] \\
\hline & \multirow{2}{*}{ Reactive blue 19} & SWNRM & 4 & 250.00 & [48] \\
\hline & & SWNRM-400 & 4 & 416.70 & [48] \\
\hline \multirow{7}{*}{ Basic } & Crystal violet & RM-HCl & $>3.2$ & 60.50 & [39] \\
\hline & & $\mathrm{RM}-\mathrm{H}_{2} \mathrm{O}_{2}$ & 8 & 16.72 & [47] \\
\hline & & RM-Heat & 10 & 0.48 & [18] \\
\hline & Methylene blue & $\mathrm{RM}-\mathrm{HNO}_{3}$ & 10 & 1.02 & [18] \\
\hline & & GRM & 11 & 5.13 & [70] \\
\hline & & $\mathrm{RM}-500^{\circ} \mathrm{C}$ & $2-4$ & 178.40 & [71] \\
\hline & Rhodamine B & $\mathrm{RM}-\mathrm{H}_{2} \mathrm{O}_{2}$ & 1 & 5.56 & [47] \\
\hline
\end{tabular}

2,4-dichlorophenol from wastewater using $\mathrm{H}_{2} \mathrm{O}_{2}$ treated red mud evolved through a particle diffusion mechanism [73]. The removal of 2,4-dichlorophenol and 4-chlorophenol ranged between 94 and $97 \%$, while the removal of 2-chlorophenol and phenol ranged between 50 and $81 \%$. Column experiments with a flow rate of $0.5 \mathrm{~mL} \mathrm{~min}{ }^{-1}$ removed $98 \%$ phenols and its derivatives in the following order 2,4-dichlorophenol $>$ 4-chlorophenol $>$ 2-chlorophenol $>$ phenol.

\subsection{Applications in Catalysis}

Red mud features in a wide range of catalytic applications, such as hydrochlorination, hydroliquefaction, hydrogenation and oxidation. Physico-chemical treatments such as acid activation, calcination, reduction, and sulphidation influence the catalytic activity of red mud [5, 12]. Metallic oxides such as iron oxides in red mud are less susceptible to poisoning by sulphur, however, the low level of dispersion and low surface area of red mud are detrimental to the catalytic activity. The interaction of calcium and sodium oxides in the red mud with the major components $\left(\mathrm{Fe}_{2} \mathrm{O}_{3}, \mathrm{Al}_{2} \mathrm{O}_{3}, \mathrm{TiO}_{2}, \mathrm{SiO}_{2}\right)$ leads to morphologic and crystallographic changes under reaction conditions required for catalytic activity. Pratt and Christoverson [74] have proposed a dissolution-precipitation method to reduce the $\mathrm{Na}$ and $\mathrm{Ca}$ content in red mud. This method involved the dissolution of red mud in strong acid, $\mathrm{HCl}$ and precip- itation with ammonia at $\mathrm{pH} 8$, which resulted in a material with high surface area and enhanced catalytic activity. Table 6 shows selected treatment methods that result in an increase in the surface area of red mud.

The removal of volatile organic compounds (VOCs), such as alkanes, aromatics, and oxygenated compounds have been investigated using iron-based catalysts prepared from red mud by dissolution-precipitation methods, followed by calcination in air at $500^{\circ} \mathrm{C}$ [75]. ARM prepared from Pratt and Christoverson method was found to be more active than PARM prepared by dissolving red mud in a mixture of hydrochloric acid and ortho-phosporic acid. The catalytic activity was observed to be similar to that of pure $\mathrm{Fe}_{2} \mathrm{O}_{3}$ and $\mathrm{Cu}-\mathrm{Cr}-\mathrm{Ti}$ commercial catalysts.

The catalytic activity of red mud can also be improved by impregnation with metals such as $\mathrm{Au}, \mathrm{Cu}$, $\mathrm{Cr}$ etc., which in addition to acting as support materials, they also contribute to increasing the catalytic activity [12]. Acid treatment and calcination at $400^{\circ} \mathrm{C}$ was found to increase both the BET surface area of red mud from $23.0 \mathrm{~m}^{2} \mathrm{~g}^{-1}$ to $124.9 \mathrm{~m}^{2} \mathrm{~g}^{-1}$ and its catalytic activity [76]. HCl treated red mud (HRM) with platinum loading $(\mathrm{Pt} / \mathrm{HRM})$ prepared through an impregnation method was found to be more active than platinum supported $\gamma-\mathrm{Al}_{2} \mathrm{O}_{3}(\mathrm{Pt} / \mathrm{Al})$ catalysts. An increase in the platinum loading from $0.1 \%$ to $1 \%$ on HRM (400) resulted in an increase

Table 6. Effect of Different Treatment Methods on the Surface Area of the Red Mud [12]

\begin{tabular}{cccc}
\hline Catalyst & Surface area, $\mathbf{m}^{\mathbf{2}} \mathbf{~}^{\mathbf{- 1}}$ (before treatment, $\left.\boldsymbol{A}_{\mathbf{0}}\right)$ & Surface area, $\mathbf{~ m}^{\mathbf{2}} \mathbf{g}^{\mathbf{- 1}}$ (after treatment, $\left.\boldsymbol{A}_{\boldsymbol{i}}\right)$ & {$\left[\left(\boldsymbol{A}_{\boldsymbol{i}}-\boldsymbol{A}_{\mathbf{0}}\right) / \boldsymbol{A}_{\mathbf{0}}\right] \mathbf{x} \mathbf{1 0 0}, \mathbf{\%}$} \\
\hline $\mathrm{ARM}^{\mathrm{a}}$ & 64.0 & 155.0 & 1.42 \\
$\mathrm{ARM}^{\mathrm{a}}$ & 25.5 & 184.1 & 6.21 \\
$\mathrm{ARM}^{\mathrm{a}}$ & 29.4 & 60.7 & 1.06 \\
$\mathrm{ARM}^{\mathrm{a}}$ & 24.3 & 82.4 & 2.39 \\
$\mathrm{SARM}^{\mathrm{c}}$ & 24.3 & 85.4 & 2.51 \\
$\mathrm{SRM}^{\mathrm{c}}$ & 24.3 & 29.5 & 0.21 \\
$\mathrm{ARM}^{\mathrm{a}}$ & 28.3 & 131.1 & 3.63 \\
$\mathrm{PARM}^{\mathrm{b}}$ & 28.3 & 111.7 & 2.94 \\
\hline
\end{tabular}

${ }^{\mathrm{a} A R M}-\mathrm{HCl}$ activated red mud.

${ }^{\mathrm{b}} \mathrm{PARM}-\mathrm{HCl}+\mathrm{H}_{3} \mathrm{PO}_{4}$ activated red mud.

${ }^{\mathrm{c}} \mathrm{SRM}$-Sulphided red mud. 
in the toluene $\mathrm{T}_{50}$ conversion from $289^{\circ} \mathrm{C}$ to $253^{\circ} \mathrm{C}$ and $\mathrm{T}_{90}$ conversion from $330 \mathrm{C}$ to $253^{\circ} \mathrm{C}$, which was accredited to an augmentation of the redox properties of the catalyst. Benzene, hexane, toluene, and o-xylene were completely oxidized over the $1 \mathrm{wt} \% \mathrm{Pt} / \mathrm{HRM}(400)$ catalysts at a temperature less than $280^{\circ} \mathrm{C}$.

Red mud and fly ash have also been used in the preparation of Ru-based catalysts, which were tested for the catalytic ammonia decomposition to hydrogen [77]. In this case, the red mud supported $\mathrm{Ru}$ catalysts exhibited higher ammonia conversion of $11 \%$ and hydrogen production of $7.4 \%$ compared to the fly-ash-supported catalyst which yielded $7 \%$ ammonia conversion and $4.2 \%$ of hydrogen production.

\subsection{Red Mud Use in Building Materials}

Building materials (bricks, cement, lime and their subsidiaries) are becoming increasingly uneconomical because of obsolescence, exhaustion of raw materials, low plant efficiencies and increasing costs [78]. The use of red mud as a replacement for cement in the production of cementitious with mechanical, microstructure, and hygroscopic properties which is suitable to use in the civil construction sector has been demonstrated [79]. The incorporation of industrial by-products in building materials may lead to concern regarding the presence of natural radionuclides in the component materials. However, bauxite and red mud contents in special cement appear to be viable from radiological aspect [80]. Naturally occurring radioactive materials (NORM) such as ${ }^{40} \mathrm{~K},{ }^{232} \mathrm{Th}$, and ${ }^{226} \mathrm{Ra}$ in the construction materials were evaluated using 68 red mud samples and 27 clay samples collected from different Hungarian building material processing plants [81]. The samples surveyed using gamma spectrometry and screened in accordance with European Basic Safety Standards (BSS) I-index were classified as bulk building materials (those having I-index $<1$ ) while those sample with large I-index (1.3 to 3.0) were proposed for mixing with cement in proportions between $12-39 \%$ of red mud (on average $25 \%$ ).

Cement produced from bauxite, lime, and red mud, or bauxite, gypsum, lime and red mud, usually exhibit strengths equivalent or greater than ordinary Portland cement. The cementitious behaviour of red mud derived from the bauxite-calcination $\left(400-900^{\circ} \mathrm{C}\right)$ method has been investigated [82]. Red mud calcined at $600^{\circ} \mathrm{C}$ possesses good cementitious properties, which results from a poorly crystallized $\mathrm{Ca}_{2} \mathrm{SiO}_{4}$ metastable phase. This metastable phase transforms into highy-crystallized $\mathrm{Ca}_{2} \mathrm{SiO}_{4}$ when the calcination temperature increased from $700^{\circ} \mathrm{C}$ to $900^{\circ} \mathrm{C}$. Figure S7 shows the XRD patterns of $\mathrm{Ca}_{2} \mathrm{SiO}_{4}$ in calcined and uncalcined red mud, at temperatures ranging from $400^{\circ} \mathrm{C}$ to $900^{\circ} \mathrm{C}$.

The possibility of partial replacement of Portland cement in concrete with red mud and the properties of the hardened concrete have been reported and compared with the conventional concrete [83]. It was revealed that up to $15 \%$ of cement may be replaced with red mud before split tensile strength, comprehensive strength and flexural strength began to decrease, particularly with regards to the comprehensive strength at 20,25 and $30 \%$ of red mud. Another study has shown that the addition of $3.5 \%$ of red mud in the raw meal for the production of Portland cement clinkers had no effect on the mineralogical characteristics and quality of the Portland cement clicker produced [21].

A new alkali-slag-red mud cementitious material (ASRC), with both high early and ultimate strength and excellent resistance against chemical attacks, has been described [84]. The hydration products of ASRC cement are made by a C-S-H gel with low $\mathrm{Ca} / \mathrm{Si}$ ratio of 0.8-1.2 in very fine size and irregular shapes. Neither $\mathrm{Ca}(\mathrm{OH})_{2}$ and Aft (alumina, ferric oxide, and tri-sulfate), which are usually present in Portland cement, nor zeolite-like products were found in ASRC. The hydration products of the final material remained similar, irrespective of the type of activator used (simple or composite) and curing condition (ambient temperature curing or steam curing).

Conventional bricks are usually produced from ordinary Portland cement or from concrete clay with high temperature kiln firing, and thus contain high embodied energy and have a large carbon footprint. Recently, extensive studies on brick production from waste materials evolved from the shortage of natural source material for the production of the conventional bricks. The alkaline content

Table 7. Various Applications Involving Red Mud as Catalyst [12, 75-77]

\begin{tabular}{|c|c|c|c|}
\hline Catalyst & Application & Temperature, ${ }^{\circ} \mathrm{C}$ & Conversion, \% \\
\hline ARM & Methane combustion & 530 & 50 \\
\hline ARM & Naphthalene hydrogenation & 405 & 80 \\
\hline ARM & Naphthalene hydrogenation & 350 & 49 \\
\hline PARM & Methane combustion & 557 & 50 \\
\hline $\mathrm{Ru} / \mathrm{RMHNO}_{3}-700$ & Ammonia conversion & 550 & 17 \\
\hline $\mathrm{Cu}-\mathrm{RM}$ & Nitric oxide oxidation & 350 & 50 \\
\hline Calcined-RM & Organochlorinated compounds hydrodechlorination & 300 & 39 \\
\hline Sulphur promoted RM & Coal liquefaction & 450 & $7.2 \mathrm{~mol}$ \\
\hline $\mathrm{RM}$ & Methane combustion & $>650$ & 50 \\
\hline $\mathrm{RM}$ & Coal hydrogenation & 400 & $>90$ \\
\hline $\mathrm{RM}$ & $\mathrm{SO}_{2}$ reduction & 640 & 30 \\
\hline Pt/HRM-400 & Toluene conversion & 253 & 90 \\
\hline Pt/HRM-400 & Hexane coversion & 240 & 90 \\
\hline Pt/HRM-400 & Benzene & 266 & 90 \\
\hline Pt/HRM-400 & o-xylene & 265 & 90 \\
\hline
\end{tabular}


in red mud (4 - 5\%) provides good fluxing action in good plasticity and better bonding in bricks. The pale brown or golden yellow colour of the bricks from red mud depend on upon the raw material composition and firing temperature [5]. To explore the possibility of producing building materials for commercial applications, paving blocks using FARM10 and FARM20 compositions have been produced on $100 \mathrm{~kg}$ scale (Fig. S8). Kumar and Kumar [85] mixed the red mud and fly ash together with $6 \mathrm{M}$ of $\mathrm{NaOH}$ and $\mathrm{Na}_{2} \mathrm{SiO}_{3} \cdot 9 \mathrm{H}_{2} \mathrm{O}$ $\left(\mathrm{SiO}_{2} / \mathrm{Na}_{2} \mathrm{O}\right.$ molar ratio $\left.=1.5\right)$ into $1: 1$ and ratio. After mixing the dough was cured at ambient temperature for $28 \mathrm{~d}$. The developed paving blocks using 10 - 20\% red mud was found to meet IS 15658 specifications. These blocks were also found to be environmentally safe with regards to the leaching of toxic and non-toxic metals.

\section{Conclusions}

This review article has underlined that raw red mud poses a significant threat to the environment and public health and that it is therefore critical to find feasible approaches to reduce the environmental impact of this industrial waste product. The hydroxides content in red mud make it highly caustic and current disposal practice in landfills creates ecological problems. Red mud has been observed to be a useful by-product for the removal of various types of metal ions, inorganic ions, and dye molecules from wastewater, however, fewer studies have focused on the removal of phenols and other organic water contaminants. It is a well-known fact that the red mud works far superior for pollutants removal if it is first activated with acids, $\mathrm{CO}_{2}, \mathrm{H}_{2} \mathrm{O}_{2}$ and by calcination at high temperatures. The modifications of unprocessed red mud with strong acids or heat treatment below $700^{\circ} \mathrm{C}$ have been found to remarkably enhance the sorption capacities in numerous studies. Among different parameters, $\mathrm{pH}$ is an essential factor influencing the sorption process. There are still a few issues that need more consideration, such as improvement of sorption limit through alteration and assessment of sorbent for multi-component pollutants.

Even though red mud offers a wide field of applications in catalysis, the rapid deactivation of its catalytic activity means that little efforts have been made to improve its use in catalysis. Red mud also has the capability to be used as a catalyst support. Extensive use of red mud in the production of building materials such as bricks, cement, and cement clinkers are environmentally beneficial and economically feasible. Tests have demonstrated that these products are safe to the environment. Further investigations on the mechanism of adsorption and precipitation that governs the removal of pollutants in solid and liquid phase should also be intensively conducted, particularly in pilot and field trials, to promote these new processes. In doing so, we may have an opportunity of turning a hazardous waste to a useful wealthy product.

\section{Acknowledgment}

This research was supported by the Research Management Centre, Universiti Putra Malaysia in collaboration with the Centre for Research \& Innovation of Universiti Malaysia Sabah (Grant No. RACE0008-ST-2013) and is gratefully acknowledged.

\section{Author Contributions}

C.G.J. (Associate Professor) supervised the student, visualised, wrote and edited the manuscript. T-Y.Y.H (Professor) made funding acquisition, wrote and edited the manuscript. V.K. (M.Sc. student) conducted the research and investigation process and wrote the original draft. G.L.P (Professor) visualised, wrote, reviewed and edited the manuscript.

\section{References}

1. Zhu X, Li W, Guan X. An active dealkalization of red mud with roasting and water leaching. J. Hazard. Mater. 2015;286: 85-91.

2. Kobya M, Oncel MS, Demirbas E, Şik E, Akyol A, Ince M. The application of electrocoagulation process for treatment of the red mud dam wastewater from Bayer's process. J. Environ. Chem. Eng. 2014;2:2211-2220.

3. Antunes MLP, Couperthwaite SJ, Da Conceição FT, et al. Red mud from Brazil: Thermal behavior and physical properties. Ind. Eng. Chem. Res. 2012;51:775-779.

4. Mišík M, Burke IT, Reismüller M, et al. Red mud a byproduct of aluminum production contains soluble vanadium that causes genotoxic and cytotoxic effects in higher plants. Sci. Total Environ. 2014;493:883-890.

5. Samal S, Ray AK, Bandopadhyay A. Proposal for resources, utilization and processes of red mud in India - A review. Int. J. Miner. Process. 2013;118:43-55.

6. Liu Y, Naidu R. Hidden values in bauxite residue (red mud): Recovery of metals. Waste Manag. 2014;34:2662-2673.

7. Gupta VK, Gupta M, Sharma S. Process Development for the Removal of Lead and Chromium from Aqueous Solutions using Red Mud an Aluminium Industry Waste. Water Res. 2001;35: 1125-1134.

8. Genç-Fuhrman H, Bregnhøj H, McConchie D. Arsenate removal from water using sand-red mud columns. Water Res. 2005;39: 2944-2954.

9. Sahu MK, Mandal S, Dash SS, Badhai P, Patel RK. Removal of $\mathrm{Pb}$ (II) from aqueous solution by acid activated red mud. J. Environ. Chem. Eng. 2013;1:1315-1324.

10. Shirzad-Siboni M, Jafari SJ, Giahi O, Kim I, Lee SM, Yang JK. Removal of acid blue 113 and reactive black 5 dye from aqueous solutions by activated red mud. J. Ind. Eng. Chem. 2014;20:1432-1437.

11. Ye J, Cong X, Zhang P, et al. Interaction between phosphate and acid-activated neutralized red mud during adsorption process. Appl. Surf. Sci. 2015;356:128-134.

12. Sushil S, Batra VS. Catalytic applications of red mud, an aluminium industry waste: A review. Appl. Catal. B Environ. 2008;81:64-77.

13. Wang S, Ang HM, Tadé MO. Novel applications of red mud as coagulant, adsorbent and catalyst for environmentally benign processes. Chemosphere. 2008;72:1621-1635.

14. Rai S, Wasewar KL, Mukhopadhyay J, Yoo CK, Uslu H. Neutralization and utilization of red mud for its better waste management. Arch. Environ. Sci. 2012;6:13-33. 
15. Ma S hua, Wen Z guo, Chen J ning, Zheng S li. An environmentally friendly design for low-grade diasporic-bauxite processing. Miner. Eng. 2009;22:793-798.

16. Wang P, Liu DY. Physical and Chemical Properties of Sintering Red Mud and Bayer Red Mud and the Implications for Beneficial Utilization. Materials (Basel). 2012;5:1800-1810.

17. Brunori C, Cremisini C, Massanisso P, Pinto V, Torricelli L. Reuse of a treated red mud bauxite waste: Studies on environmental compatibility. J. Hazard. Mater. 2005;117:55-63.

18. Wang S, Boyjoo Y, Choueib A, Zhu ZH. Removal of dyes from aqueous solution using fly ash and red mud. Water Res. 2005;39:129-138.

19. Komnitsas K, Bartzas G, Paspaliaris I. Efficiency of limestone and red mud barriers: Laboratory column studies. Miner. Eng. 2004;17:183-194.

20. Bertocchi AF, Ghiani M, Peretti R, Zucca A. Red mud and fly ash for remediation of mine sites contaminated with As, $\mathrm{Cd}, \mathrm{Cu}, \mathrm{Pb}$ and Zn. J. Hazard. Mater. 2006;134:112-119.

21. Tsakiridis PE, Agatzini-Leonardou S, Oustadakis P. Red mud addition in the raw meal for the production of Portland cement clinker. J. Hazard. Mater. 2004;116:103-110.

22. Li P, Miser DE, Rabiei S, Yadav RT, Hajaligol MR. The removal of carbon monoxide by iron oxide nanoparticles. Appl. Catal. B Environ. 2003;43:151-162.

23. Yalçin N, Sevinç V. Utilization of bauxite waste in ceramic glazes. Ceram. Int. 2000;26:485-493.

24. Sglavo VM, Campostrini R, Maurina S, et al. Bauxite "red mud" in the ceramic industry. Part 1: thermal behaviour. J. Eur. Ceram. Soc. 2000;20:235-244.

25. Jústiz-Smith N, Buchanan VE, Oliver G. The potential application of red mud in the production of castings. Mater. Sci. Eng. A. 2006;420:250-253.

26. Collazo A, Fernández D, Izquierdo M, Nóvoa XR, Pérez C. Evaluation of red mud as surface treatment for carbon steel prior painting. Prog. Org. Coatings. 2005;52:351-358.

27. Kurtoğlu SF, Soyer-Uzun S, Uzun A. Tuning structural characteristics of red mud by simple treatments. Ceram. Int. 2016;42:17581-17593.

28. Huang W, Wang S, Zhu Z, et al. Phosphate removal from wastewater using red mud. J. Hazard. Mater. 2008;158:35-42.

29. Liang W, Couperthwaite SJ, Kaur G, Yan C, Johnstone DW, Millar GJ. Effect of strong acids on red mud structural and fluoride adsorption properties. J. Colloid. Interface. Sci. 2014;423:158-165.

30. Santona L, Castaldi P, Melis P. Evaluation of the interaction mechanisms between red muds and heavy metals. J. Hazard. Mater. 2006;136:324-329.

31. Liu Y, Lin C, Wu Y. Characterization of red mud derived from a combined Bayer Process and bauxite calcination method. J. Hazard. Mater. 2007;146:255-261.

32. Palmer SJ, Nothling M, Bakon KH, Frost RL. Thermally activated seawater neutralised red mud used for the removal of arsenate, vanadate and molybdate from aqueous solutions. J. Colloid. Interface. Sci. 2010;342:147-154.

33. Sahu RC, Patel RK, Ray BC. Neutralization of red mud using $\mathrm{CO}_{2}$ sequestration cycle. J. Hazard. Mater. 2010;179:28-34.

34. Altundoan HS, Altundoan S, Tümen F, Bildik M. Arsenic adsorp- tion from aqueous solutions by activated red mud. Waste Manag 2002;22:357-363.

35. Genç H, Tjell JC, McConchie D, Schuiling O. Adsorption of arsenate from water using neutralized red mud. J. Colloid. Interface. Sci. 2003;264:327-334.

36. Li Y, Liu C, Luan Z, et al. Phosphate removal from aqueous solutions using raw and activated red mud and fly ash. J. Hazard. Mater. 2006;137:374-383.

37. Liu CJ, Li YZ, Luan ZK, Chen ZY, Zhang ZG, Jia ZP. Adsorption removal of phosphate from aqueous solution by active red mud. J Environ Sci. 2007;19:1166-1170.

38. Tor A, Cengeloglu Y. Removal of congo red from aqueous solution by adsorption onto acid activated red mud. J. Hazard. Mater. 2006;138:409-415.

39. Zhang L, Zhang H, Guo W, Tian Y. Removal of malachite green and crystal violet cationic dyes from aqueous solution using activated sintering process red mud. Appl. Clay Sci. 2014;93-94: 85-93.

40. Tor A, Cengeloglu Y, Aydin ME, Ersoz M. Removal of phenol from aqueous phase by using neutralized red mud. J. Colloid. Interface. Sci. 2006;300:498-503.

41. Zhang S, Liu C, Luan Z, Peng X, Ren H, Wang J. Arsenate removal from aqueous solutions using modified red mud. $J$. Hazard. Mater. 2008;152:486-492.

42. Han SW, Kim DK, Hwang IG, Bae JH. Development of pellet-type adsorbents for removal of heavy metal ions from aqueous solutions using red mud. J. Ind. Eng. Chem. 2002;8:120-125.

43. Zhao Y, Yue Q, Li Q, Gao B, Han S, Yu H. The regeneration characteristics of various red mud granular adsorbents (RMGA) for phosphate removal using different desorption reagents. J. Hazard. Mater. 2010;182:309-316.

44. Zhu C, Luan Z, Wang Y, Shan X. Removal of cadmium from aqueous solutions by adsorption on granular red mud (GRM). Sep. Purif. Technol. 2007;57:161-169.

45. Tor A, Danaoglu N, Arslan G, Cengeloglu Y. Removal of fluoride from water by using granular red mud: Batch and column studies. J. Hazard. Mater. 2009;164:271-278.

46. Gupta VK, Sharma S. Removal of cadmium and zinc from aqueous solutions using red mud. Environ. Sci. Technol. 2002;36: 3612-3617.

47. Gupta VK, Suhas, Ali I, Saini VK. Removal of rhodamine B, fast green, and methylene blue from wastewater using red mud, an aluminum industry waste. Ind Eng Chem Res. 2004;43: 1740-1747.

48. de Souza KC, Antunes MLP, Couperthwaite SJ, da Conceição FT, de Barros TR, Frost R. Adsorption of reactive dye on seawater-neutralised bauxite refinery residue. J. Colloid. Interface. Sci. 2013;396:210-214.

49. Altundoğan HS, Tümen F. As(V) removal from aqueous solutions by coagulation with liquid phase of red mud. J. Environ. Sci. Health A Tox. Hazard. Subst. Environ. Eng. 2003;38:1247-1258.

50. Wang Q, Luan Z, Wei N, Li J, Liu C. The color removal of dye wastewater by magnesium chloride/red mud (MRM) from aqueous solution. J. Hazard. Mater. 2009;170:690-698.

51. Orescanin V, Nad K, Mikelic L, Mikulic N, Lulic S. Utilization of bauxite slag for the purification of industrial wastewaters. Process Saf. Environ. Prot. 2006;84:265-269. 
52. Poulin Ê, Blais JF, Mercier G. Transformation of red mud from aluminium industry into a coagulant for wastewater treatment. Hydrometallurgy. 2008;92:16-25.

53. Zhao Y, Zhang LY, Ni F, et al. Evaluation of a novel composite inorganic coagulant prepared by red mud for phosphate removal. Desalination. 2011;273:414-420.

54. Lu R, Zhang Y, Zhou F, Wang X, An Q, Meng Z. Novel polyaluminum ferric chloride composite coagulant from Bayer red mud for wastewater treatment. Desalin. Water Treat. 2014;52: 7645-7653.

55. Ni F, He J, Wang Y, Luan Z. Preparation and characterization of a cost-effective red mud/polyaluminum chloride composite coagulant for enhanced phosphate removal from aqueous solutions. J. Water Process. Eng. 2015;6:158-165.

56. Vaclavikovaa M, Misaelidesb P, Galliosb G, Jakabskya S, Hredzaka S. Removal of cadmium, zinc, copper and lead by red mud, an iron oxides containing hydrometallurgical waste. Stud Surf Sci Catal. 2005;155:517-525.

57. Sanchez TR, Perzanowski M, Graziano JH. Inorganic arsenic and respiratory health, from early life exposure to sex-specific effects: A systematic review. Environ. Res. 2016;147:537-555.

58. Schlebusch CM, Gattepaille LM, Engström K, Vahter M, Jakobsson M, Broberg K. Human adaptation to arsenic-rich environments. Mol. Biol. Evol. 2015;32:1544-1555.

59. Benramdane L, Accominotti M, Fanton L, Malicier D, Vallon JJ. Arsenic speciation in human organs following fatal arsenic trioxide poisoning-a case report. Clin. Chem. 1999;45:301-306.

60. Altundoğan HS, Altundoğan S, Tümen F, Bildik M. Arsenic Removal from Aqueous Solutions by Adsorption on Red Mud. Waste Manag. 2000;20:761-767.

61. Rubinos DA, Arias M, Díaz-Fierros F, Barral MT. Speciation of adsorbed arsenic(V) on red mud using a sequential extraction procedure. Mineral Mag. 2005;69:591-600.

62. Cengeloglu Y, Tor A, Arslan G, Ersoz M, Gezgin S. Removal of boron from aqueous solution by using neutralized red mud. J. Hazard. Mater. 2007;142:412-417.

63. H. Genc-Fuhrman, $\mathrm{PhD}$ Thesis, Environment \& Resources DTU Technical University of Denmark, Denmark, 2004

64. L. Sigg, in: W. Stumm (Ed.), Aquatic Surface Chemistry, Chemical Processes at the Particle Water-Interface, Wiley, New York, 1987, p. 325.

65. Yue Q, Zhao Y, Li Q, et al. Research on the characteristics of red mud granular adsorbents (RMGA) for phosphate removal. J. Hazard. Mater. 2010;176:741-748.

66. Zhao Y, Yue Q, Li Q, et al. Characterization of red mud granular adsorbent (RMGA) and its performance on phosphate removal from aqueous solution. Chem. Eng. J. 2012;193-194:161-168.

67. Cengeloglu Y, Tor A, Ersoz M, Arslan G. Removal of nitrate from aqueous solution by using red mud. Sep. Purif. Technol. 2006;51:374-378.

68. Carneiro PA, Umbuzeiro GA, Oliveira DP, Zanoni MVB. Assessment of water contamination caused by a mutagenic textile effluent/dyehouse effluent bearing disperse dyes. $J$. Hazard. Mater. 2010;174:694-699.
69. Ratnamala GM, Shetty KV. Removal of Remazol Brilliant Blue Dye from Dye-Contaminated Water by Adsorption Using Red Mud: Equilibrium, Kinetic, and Thermodynamic Studies. Water Air Soil Pollut. 2012;223:6187-6199.

70. Le TQX, Wang H, Ju S, Peng J, Zhou L, Dai L. Column absorption and regeneration behavior of a granular red mud for treating wastewater containing methylene blue. Desalin. Water Treat. 2016;57:728-737.

71. de Jesus CPC, Antunes MLP, da Conceição FT, Navarro GRB, Moruzzi RB. Removal of reactive dye from aqueous solution using thermally treated red mud. Desalin. Water Treat. 2015;55:1040-1047.

72. Tor A, Cengeloglu Y, Ersoz M. Increasing the phenol adsorption capacity of neutralized red mud by application of acid activation procedure. Desalination 2009;242:19-28.

73. Gupta VK, Ali I, Saini VK. Removal of chlorophenols from wastewater using red mud: An aluminum industry waste. Environ. Sci. Technol. 2004;38:4012-4018.

74. Pratt KC, Christoverson V. Hydrogenation of a model hydrogen-donor system using activated red mud catalyst. Fuel 1982;61:460-462.

75. Paredes JR, Ordóñez S, Vega A, Díez FV. Catalytic combustion of methane over red mud-based catalysts. Appl. Catal. B Environ. 2004;47:37-45.

76. Kim SC, Nahm SW, Park Y-K. Property and performance of red mud-based catalysts for the complete oxidation of volatile organic compounds. J. Hazard. Mater. 2015;300:104-113.

77. Pei FN, Li L, Wang S, Zhu Z, Lu G, Yan Z. Catalytic ammonia decomposition over industrial-waste-supported $\mathrm{Ru}$ catalysts. Environ. Sci. Technol. 2007;41:3758-3762.

78. Sawant AB, Kumthekar MB, Sawant SG, Mud AR. Utilization of Neutralized Red Mud (Industrial Waste) in Concrete. Int. J. Inven. Eng. Sci. 2013;1:9-13.

79. Manfroi EP, Cheriaf M, Rocha JC. Microstructure, mineralogy and environmental evaluation of cementitious composites produced with red mud waste. Constr. Build Mater. 2014;67:29-36.

80. Somlai J, Jobbágy V, Kovács J, Tarján S, Kovács T. Radiological aspects of the usability of red mud as building material additive. J. Hazard. Mater. 2008;150:541-545.

81. Sas Z, Somlai J, Szeiler G, Kovács T. Usability of clay mixed red mud in Hungarian building material production industry. J. Radioanal Nucl. Chem. 2015;306:271-275.

82. Liu X, Zhang N, Sun H, Zhang J, Li L. Structural investigation relating to the cementitious activity of bauxite residue - Red mud. Cem. Concr. Res. 2011;41:847-853.

83. Linora Metilda D, Selvamony C, Anandakumar R, Seeni A. Experimental investigation on optimum possibility of replacing cement by redmud. Int. J. Appl. Eng. Res. 2015;10:4569-4578.

84. Pan Z, Cheng L, Lu Y, Yang N. Hydration products of alkali-activated slag-red mud cementitious material. Cem Concr Res. 2002;32:357-362.

85. Kumar A, Kumar S. Development of paving blocks from synergistic use of red mud and fly ash. Constr. Build. Mater. 2013;38:865-871. 